\title{
Language Allergy: Seduction and Second Languages in How the García Girls Lost Their Accents
}

\author{
Juan Pablo Rivera \\ Westfield State College, USA
}

\begin{abstract}
:
This paper explores the construction of a bilingual, female, heterosexual subjectivity in Dominican-American author Julia Alvarez's How the García Girls Lost Their Accents. The paper argues that the theoretical excesses in the narrative revolve around a bilingual difference that problematizes heterosexuality's efforts to become a hegemonic discourse.
\end{abstract}

Keywords: Julia Alvarez, Language, allergy, bilingual, sexuality.

Towards the end of the first chapter of How the Garcia Girls Lost Their Accents, the protagonist, Yolanda, develops a strange allergy. Certain words, when she pronounces them herself, will cause her face to flare up with hives, her eyes to water, her breathing to become short and heavy. Two semantic fields are particularly noxious: words related to "love" and words related to "life," including the different nicknames Yolanda has assigned herself, or has been assigned, after her family's arrival in the United States: "Yo," "Joe," "Yoyo." Migrants, the novel reminds us, gain names as they gain identities, a reason why diasporic literatures are overwrought with reflections about the challenges of translating one's self. As Julia Alvarez's narrator reiterates, names demand at least one explanation in the ears of interlocutors who have a tough time pronouncing them. ${ }^{i}$

Yolanda's allergy to her own name is the physical manifestation of being posessed by one's language, as if the wild tongue that Gloria Anzaldúa theorized had turned against the new mestiza that claimed its proud posession. As Alvarez and Anzaldúa know well, wild tongues sting inwardly as well as outwardly; perhaps that is why my own tongue-far more at home in Spanish than English-stumbles between "Yo" and "Joe," between that evident, almost too evident stand-in for the first person singular pronoun in Spanish and that genderneutral American nickname, Joe.

Yoyo, it turns out, is as uncertain about her given name as she is about love. Much to the chagrin of her "proudly monolingual" (Alvarez 72) lovers, her confusion is compounded by the fact that, as Doris Sommer (Aesthetics xix; 45) reminds Jacques Derrida, names mean different things in different languages. In Monolingualism of the Other, Derrida waxes romantically on "one" who "can, of course, speak several languages... But do they not always do it with a view to an

Rupkatha Journal on Interdisciplinary Studies in Humanities (ISSN 0975-2935), Vol 2, No 2, 2010 URL of the Issue: http://rupkatha.com/v2n2.php

URL of the article: http://rupkatha.com/V2/n2/HowGarciaGirlsLostTheirAccents.pdf

(C) www.rupkatha.com 
absolute idiom? And in the promise of a still-unheard-of language? Of a sole poem previously inaudible?" (Monolingualism 58). Sommer disagrees: "No, Jacques, not always," she writes. "When bilinguals pause to worry about missing pieces, it may be to poach a patch from parallel codes. Sometimes the sutures flaunt their seams, to make worry an aesthetic or ideological effect" (Aesthetics 45).

In this essay I contend that the only effective relationships (amorous, professional, familial) in The García Girls take place between people who live multilingually and relish the irritation that this linguistic hodgepodge might provoke. These relationships flourish between people who are content when, as Sommer put it, bilingual "sutures flaunt their seams." I base my definition of effective relationships, as the novel does, less on the concept of tolerance than on the concept of understanding. These relationships take place between people "obviously much taken with words and their meanings" (Alvarez 93). In this novel, "words and their meanings" are a bilingual's preoccupation, except in the case of one Rudolf Brodermann Elmenhurst, Yolanda's first college love, "who also had an odd name and who was out of it [out of place] because he wasn't there" (89). Notice how the phrase above is tautological. And tautologies are fine. The novel opens a space for such linguistic misfire. This revaloration of misfiring runs counter to traditional readings of The García Girls that interpret linguistic confusion as communicative failure." Regardless of their linguistic skill and unfamiliarity with speech-act theory, bilingual characters in The García Girls are well aware that words make things happen, or that they do not, as when Yolanda's father, Carlos, "enumerated the names of famous Charleses in order to stir up genetic ambition in" (Alvarez 26) his grandson.

There is a theoretical excess in Alvarez's narrative whereby the confusion of being in love is echoed in the confusion of speaking more than one language. "Confusion" here is not understood negatively, but rather as the characteristic struggle of a consciousness to come into terms with its conditions. As Martha Nussbaum has argued, confusion is a defining aspect of love's knowledge. knowledge that one is in love is a confusing knowledge-a proposition that challenges the notion that knowledge is somehow self-contained, whole, that knowledge, if it is "true" knowledge, does not doubt itself. It is a knowledge, Nussbaum writes, whereby "we find ourselves asking where, in this plurality of discordant voices with which we address ourselves on this topic of perennial selfinterest, is the crierion of truth?" (261; my italics). In a recent book, Love and Language (2007), Ilan Stavans and Verónica Albin take Nussbaum's questioning further by arguing that, though it is perfectly possible for one to affirm "I am in love," for one to know one is in love, such knowledge cannot be quantified. It cannot even be defined (Stavans and Albin 1-4). What do I mean when I declare that I am in love? 
The fact that How the García Girls Lost Their Accents has sold over 350,000 copies in the United States alone points towards the seductive effect of two of its defining elements: the fascination of the American mainstream with the "tropicalism" of Caribbean cultures, and the seductive potential of stories about failed loves. Social linguists today know as well as poets that lovers make up secret codes to express their love. A classic example can be found in Ovid's treaty on seduction, the Ars Amatoria, where, in the fourth elegy, the poet and his married mistress devise a code so they may express their love to each other in the presence of the woman's husband. He instructs her to touch his foot lightly as she passes, to never take her eyes of off him, to, in J. Lewis May's translation, "secretly receive, and secretly send forth, these signals of my love" (v. 19-20). In the Hispanic literary tradition, females and friars alike shun go-betweens for their intelligence as much as for their linguistic virtuosity. ${ }^{\text {iv }}$

"Proudly monolingual" is a phrase that the Dominican American protagonist, Yolanda, known as Yo-yo for her inconsistencies, uses to describe one of her male American lovers, with the boring name of John, who could not make any decisions about love without first drafting lists of pros and cons. Used to the confusion and insights gained by Spanish and English irritating each other, Yo-yo ultimately concludes that she and John just didn't speak the same language. The novel does not simply oppose, as some critics have argued, a feminine language, babelian and organic, to an orderly, logical, male one. In fact, the only male in the novel with whom Yolanda is ultimately able to communicate sucessfully is her boss who, unfortunately, happens to be married. He also happens to be a professor of comparative literature. Alhough he and Yolanda do not necessarily speak the same languages, they do understand each other, just as one of her sisters is imperfectly able to communicate with her German boyfriend Otto, who speaks no Spanish and can only patch together some phrases in English. The novel, thus, praises the gains and loses of bilingualism. Bilinguals understand each other, it proposes, because they are used to misunderstanding.

Such a revaluation of bilingual misfires is tangentially supported by current work on the sociology of gender and language that finds poetry in the silliness of baby talk and the private languages of newspaper ads. In a study that analyzes lovers' tendency to create intimate languages, Yo-yo gives an account of the irreverance with which two lovers engage their native tongue. They create a reality and dialect that is alternative to their public worlds, but that extracts a good part of its vocabulary and inflections from the lingo of children, the press, animal fables, television and fantasy. This alternative world, Langford writes, comes into being through the creation of a private counter-culture with its own language, codes and customs. Familiar words and phrases convey meanings to be found in no dictionary: 
All the bananas in the world. BLP.

Darling Chocolate Wease/ please marry me and have lots of rug rats.

Lots of special kisses and starbursts from your loving cuddly Koala.

--and foreign languages and cryptic expressions test the would-be interpreter, who is finally thwarted by codes which are simply untranslatable:

\section{Oink oink! \\ Grunt grunt. \\ Dow Bowow ow lowv mow bowbow lowv bowbow. \\ Hooch hooch, Hooch hooch hooch. (Langford, "Snuggle" 175)}

Lovers create between themselves a foreign tongue, the author concludes. It is unintelligible to any translator, alien to any dictionary-unsistematizable, that is, despite the best efforts of social linguists to give an account of its system.

And yet, few studies consider what happens to courtship, sex and seduction when they are facilitated, and sometimes hindered, by the intrusion of a second language. In the kind of multicultural and bilingual settings that diasporic literatures are logically fond of representing, how can knowing, not knowing, or pretending not to know a second language serve as a strategy for seduction? How might bilinguals have an upper hand when engaged in a situation that teaches us as much about love as it does about power? How might scenes of seduction continue to change as people continue to be displaced from one country to the next and from one language to the other?

While exploring the questions above, it will become evident I also propose that, by engaging in theoretical reflections of bilingualism within the context of multiple heterosexual relationships, Alvarez's narrative has a side-effect. It shows how bilingualism challenges the "phantasmatic idealization" that Judith Butler ("Imitation" 21) has attributed to heterosexuality. By revealing how heterosexuality is not ONE, how a bilingual and bicultural person might think about heterosexuality and about love differently than a monolingual person, the novel puts into question, if not the very normativity of heterosexuality, at least its idealistic and totalizing ambitions.

Julia Alvarez's work is ripe with considerations of the changing roles of foreigners in a new adoptive country, of the (im)possibility of acculturation and of the mutation that gender roles undergo as men and women are forced to flee. ${ }^{v}$ In part, the Dominican-American author appeals to a mainstream public because her writing is hardly experimental, a quality that Guillermo Irizarry discusses in an incisive critique of The Garcia Girls. Her writing, we may say, is closer to the "literatura posautónoma" that Josefina Ludmer identifies with texts that, while commercially succesful, straddle various locations and genres, with a disregard 
for traditional parameters of what may be considered literary. These literatures announce, in a sense, the end of literature as a traditional discipline and autonomous realm of knowing.

Characters in Alvarez's novels are often writers, but writers of minor genres, such as the lyric poet Salomé Ureña in In the Name of Salomé or of Dedé and her diary entries in In the Time of the Butterflies. The representations of these genres in Alvarez's novels dismount the totemic ambitions of the Novel itself; the protagonist of The García Girls is a failed lyric poet. But metalinguistic and metanarrative reflections in The García Girls have a secondary effect, as it were. Between the mismash of intimate languages and genres, a theory of bilingual subjectivity arises, perhaps even unwittingly, as a kind of bilingual remanent. In this novel, monolingualism does not promote good understanding, taken as an appreciation for unknowing and linguistic misfires. Bilingualism does, regardless of what specific languages bilinguals speak. Moreover, because relationships in The García Girls take precedence over the plot, the paradox above organizes the entire narrative. Despite the pain of immigration, and on account of it, the novel becomes a paean for the cognitive and social benefits of bilingualism.

In one of the few analyses that have attempted to link Alvarez with the greater Latin American literary tradition, William Luis remarks that the nickname "Yoyo" recalls the name of the toy. Yolanda herself alludes to this in the chapter devoted to her allergy which, not coincidentally, opens with the following reflection:

Yolanda, nicknamed $Y_{O}$ in Spanish, misunderstood Joe in English, doubled and pronounced like the toy, Yoyo-or when forced to select from a rack of personalized key chains, Joey-stands at the third-story window watching a man walk across the lawn with a tennis racket (68).

She watches from the window of the mental institution to which she has committed herself. The chapter, like the passage that opens it, painstakingly attempts to establish a link between madness and linguistic excess, and between madness and aphasia, relationships that should be familiar to any devotee of Freud's hysterics.

Yo's parents become worried because "she talked in comparisons, she spoke in riddles" (79). This sensitivity to language, as the sister Fifí calls it (60), seems to run in the family. During the girls' youth, their mother, Laura García, resorted to generic pet names for each of her daughters, shuffling their birthdates and careers as well as the names of their husbands and boyfriends (42). With four young daughters in tow, the narrator states, Laura García "couldn't indulge identities" (41). Another sister, Sandra had to be committed to a mental institution 
because she became anorexic, too enthralled by reading to remember to eat (5054). Reading the canon can kill you, Alvarez seems to joke, well aware of her literature in a minor key, as Sandra's reading list begins with Homer and ends with Freud, including, of course, a brief reference to Don Quijote.

Miryam Criado (in the keenest interpretation of this novel) correctly reads the scene above as Sandra's attempt to assimilate "un modo de expresión androcéntrico para poder disimular su otredad tanto cultural como sexual" [an androcentric way of expression in order to hide her cultural and sexual otherness] (199; my translation). But in Criado's interpretation, assimilation is always interpreted as loss, as if assimilation itself could ever be completed or finalized. The García sisters, she concludes, "han aprendido hablar [sic] en la lengua de la cultura androcéntrica dominante pero han perdido su voz como mujeres porque ese lenguaje no les sirve para explicarse a sí mismas o para expresar sus sentimientos o emociones más íntimas" [have learned to speak the language of androcentric dominant culture, but have lost their voice as women, because that language does not suffice for them to explain themselves to each other, nor to explain their feelings or most intimate emotions] (203). Her reading drafts a male-female dichotomy and ultimately renders the García sisters devoid of agency, disregarding their own twisting of the dominant androcentric culture that they can never fully join.

Having noticed this impossibility, William Luis transforms Yolanda's yo-yo into a symbol for the ways in which she oscillates between her Dominican identity and her American one, the Dance Between Two Cultures that can be joyful as well as painful. The critic adds that the structure of Alvarez's novel reminds him of Alejo Carpentier's "Viaje a la semilla," a story told backwards, as it were, without the imposition of an omniscient narrative voice that grants the story a neat coherence. The yo-yo represents, then, the messiness of acculturation, the extent to which acculturation occurs as an uneven process in a novel that, from the title, promises that acculturation has been finally, even seamlessly achieved. Thus, the yo-yo contrasts with the rack of "personalized key chains" in the earlier passage, an adult toy that attempts to fix Yolanda's name, albeit a false one, Joey.

Perhaps as a veiled rebuttal of Luis's comparison with Carpentier's story, in his critique of double-translation in How the García Girls Lost Their Accents, Guillermo Irizarry argues that any kind of formal experimentalism in the novel is flattened out by the fact that, ultimately, the narrative is structured as a biography (as a partial autobiography, other critics claim). I agree with Irizarry that, in structural terms, the novel-unlike Carpentier's sophisticated story-ends up being fairly traditional, its experimentalism tamed on account of its target audience. But I do not think--and Irizarry does not argue, either--that biography necessarily turns the narrative into a coherent, self-contained whole. Yolanda's 
story is full of narrative gaps, instances of doubling, self-doubt and metalinguistic reflections that keep this novel from being a "flat" autobiography. Whereas the Ourobouros might serve to symbolize the structure of Carpentier's story, as Roberto González Echevarría has commented (Lecture), it fails to account for the structure of Alvarez's novel, which is fragmentary rather than circular.

The serpent in Alvarez's novel never bites its tail because its fragmentary structure duplicates unevenly the fragmentation of English and Spanish that the novel evokes time and time again, a strategy that Alvarez also uses, albeit differently, in ;Yo!, a sequel of sorts to The García Girls. Yolanda's bilingualism expands the panoply of words with which to play. "Stop violeting me!," she demands of a lover who has begun to call her "shrinking Violet" (74) because she is now seeing a therapist. This lover, John, is her first lover after the married Clive, chair of the comparative literature department where Yolanda works (49). Clive breaks up his affair with Yolanda in order to return with his wife. It is my contention, however, that Yolanda is enthralled with him not because of the differences in age and social standing, as some feminisms would have it. Their understanding has more to do with the fact that he is a comparatist. He, too is used to the messiness of languages irritating each other, an awareness that John, the "proudly monolingual" lover lacks. Confusion and disonance are, after all, hallmarks of falling in love, as Martha Nussbaum (261) argues. But whereas Nussbaum draws a teleological curve (self-deception, discovery, correction) to arrive at the truth that love might hold, The García Girls rewards us with no such optimism, with no such correction. This novel follows instead the Proustian model that Nussbaum herself scrutinizes, which dictates that "knowledge of the heart must come from the heart-from and in its pains and longings, its emotional responses" (Nussbaum 262).

Yolanda's and William Luis's invocation of the yo-yo may invite comparison to Freud's asessment of Little Han's "Fort-Da," a childhood maneuver that the psychoanalyst interprets as his grandson's attempt to symbolize the trauma of his mother's absence. That would be, of course, a particularly appropriate comparison, as the shuttling between here and there is constitutive of Yolanda's life story as well as her family's and, one may argue, also determinant of her psychic life. In fact, several critics of the novel, even if without allusion to the "Fort-Da," read it from the perspective of the trauma of exile, both in physical terms and in the exilic condition of the writer. Trigo interprets Yolanda's ruminations at the end of the novel as the symbolization of a trauma that returns in writing (Trigo 138). He interprets the traumatic event as being "a guilty moment when little Yolanda removes a fragile kitten from her litter" (139). Mujcinovic, on the other hand, reads Edward Said's "rift between a human being and a native place" (qtd. in Mujcinovic 168) as pointing towards the traumatic core of exile. For her, the García girls' fleeing from Trujillo's dictatorship serves as a traumatic backdrop for the entire narrative. This trauma shows its 
symptoms through the father in the novel, who suffers from insomnia and is startled every time he sees a black van, reminiscent of Trujillo's secret police.

However, what neither Trigo nor Mujcinovic discuss, is how distinctly untraumatic the moment of exile becomes for the little García girls themselves. Their parents, having fled the Island in 1960 after failing to assasinate Trujillo, were able to disguise political persecution as play. The girls eventually learn to move, even if uncomfortably, between New York and the Dominican Republic. Thus, even if the inhabitants of the native country are packaged as a neat Other, we are far from the idyllic homeland that Augenbraum and Stavans ("Introduction") find in a previous wave of U. S. Latino/a writing. As Trigo himself puts it, Alvarez's writing in a minor key "echoes and disturbs a cultural and literary tradition that erects itself on the foundation of a lost origin" (132). I read Sandra's anorexic parody of Don Quijote as such an attempt to disturb a foundational monument by inflicting it with a supposedly feminine, "minor," malady, akin to Stavans's problematic translation of the same book into Spanglish.

It is not that Alvarez is unable to write in a more vast, epic key. She has certainly done so with Saving the World, In the Name of Salomé and In the Time of the Butterflies, a novel that often draws comparisons (Patterson) with Mario Vargas Llosa's The Feast of the Goat, given their similar subject matter and the fact that they were written by authors who are foreigners of sorts to the Dominican Republic and did not endure Trujillo's dictatorship directly. But in order to draw home the lack of traumatism and exile in The García Girls, I would like to emulate the indirectness that characterizes trauma (Caruth 60), its belatedness, and compare Vargas Llosa's novel not to In the Time of the Butterflies, but to The García Girls.

Just as Alvarez's novel opens with Yolanda's return to the Dominican Republic, The Feast of the Goat begins with Urania Cabral's return to her native country in order to settle accounts with her ailing father. Agustín Cabral, unlike Carlos García, never had the courage to conspire to assasinate Trujillo, an assasination that structures the novel's plot, counterpointed by Urania's fictional biography and her relationship to the family that she left behing after moving to the United States permanently. As is typical of other novelas del dictador like Yo, el Supremo and El Señor Presidente, Vargas Llosa's story is told in detestivesque fashion. Just as in the anonymous postings on the church billboards of Yo, el Supremo, in both The Garcia Girls and The Feast of the Goat, a secret is initally only whispered, to be unravelled by the novel's conclusion. In the case of The Feast of the Goat, the concrete reason for Uranita's return to the Dominican Republic and her despise of her father are revealed counter-chronologically, as is Yolanda's story in The García Girls. What readers eventually discover in reading the final scene of The Feast of the Goat is 
what they probably had suspected altogether, that Agustín Cabral had surrendered his only daughter's virginity to Trujillo when she was merely a teenager, so as not continue losing favor in el Chivo's eyes. This moment of sexual violence co-founds the entire narrative along with Trujillo's assasination, which, in a sense, initiates the story, as it propells it.

A hidden signifier behind Urania's name has ample sexual connotations. In the very first page of the novel, the narrator is quick to unravel the associations her name might conjure: "Urania. No le habían hecho un favor sus padres; su nombre daba la idea de un planeta, de un mineral, de todo, salvo de la mujer espigada y de rasgos finos, tez bruñida y grandes ojos oscuros, algo tristes, que le devolvía el espejo" (11). Included in this "de todo" with which the narrator signs off the associations with Urania's name, might also be the concept of "uranism" that Karl Henrich Ulrichs had coined to describe homosexuality even before such a concept existed. A suspicious reader might find this association bolstered by the fact that Urania never married, and that she shows an explainable distrust of men. Moreover, next to the last name Cabral, through metonymical association, we find, of course, "cabro," "cabrón" and "chivo," as though the very mention of Urania Cabral's name traced a perverse narrative arc between the first scene of the novel and the last, where she is raped by el Chivo.

In contrast to Vargas Llosa's narrative, trauma in Alvarez's novel is often downplayed, especially as it pertains to sexual violence. Readers are entertained by the approximation of a wound, a gap, but then the narrative retracts. An example is found in the novel's treatment of sexuality, such as the sexual misencounter between children in "The Human Body," one of the final sections of The García Girls. The scene involves a tomboyish Yolanda, her baby sister Fifí, and their cousin Mundín, whom time and time again the narrator describes as a little dictator, like most men in the novel. Yolanda has reached the age in which adults begin to frown upon tomboyism, following Judith Halberstam's argument (5-9) in Female Masculinity Yolanda reports on behalf of her mother, "I got over my tomboy phase and started acting like a young lady señorita" (228). Perversely echoing Laura's command, Mundín agrees to trade a piece of toy clay with Yolanda as long as she will "show" him she is "a girl" (233). But to Mundín's anti-climactic disappointment, Fifí and Yolanda are "just like dolls" (235). The scene is interrupted by the voice of Mundín's mother calling for him, a voice of authority that inflicts shame on Mundín's "face that was naked with worry" (235) as he had tried to do onto his cousin.

In The Feast of the Goat, Trujillo's violation of Urania is also, in a very different sense, anti-climactic. Suffering from prostatitis, the aging Chivo is unable to penetrate Urania with his penis, so he resorts to his fingers. Sexual pornography and the pornography of violence go hand in hand in this novel. The 
great mystery that the novel unravels consists of a moment of sexual violence that readers most likely had already suspected from the novel's first page. In the case of How the García Girls Lost Their Accents, sexuality offers no voyeuristic reward for Mundín. In the narrative, there is no violation, no life-altering moment, no insight into the motivation of its characters nor of sexual or erotic awareness. Readers are afforded no anagnorisis, and the moment is far from traumatic, as though it were the traumatic moment itself, and not its symptoms, that needed to be delayed, pushed towards the novel's ending. And this ending, as we may surmise from a combined reading of Trigo's and Luis's work, consists of the gash left by the intrusion of one language into another. It consists of the voice of a kitten caught inside a drum, a voice that in Yolanda's grown-up dreams calls for her mother like the voice of Tancred's lover in Caruth's (1-9) analysis of trauma in Freud. One way that Yolanda learns to deal with this voice - to give it voiceis through writing.

How, then, may we ask, do the affective relationships that the García girls establish with other bilinguals, and with their own languages, serve as a way for patching the fault lines that exist between two languages rubbing against each other? Sofia's (Fifi's) seduction of Otto provides a telling example. Fifí is, throughout the novel, the family's black sheep, ending up in Perú after having escaped college. There, at a marketplace, she overhears a German who speaks no Spanish attempting to buy a poncho (59). Fifi's Spanish, imperfect as it is, comes to the German Otto's aid, even managing to strike a bargain with the salesman. Otto gains a poncho, and Fifí a prospective husband, achievements mediated by a moment of bilingual identification where both interlocutors hardly understand each other. This moment contrasts with Yolanda's relationship with Rudy, who believes that "a spade's a spade" (96) and had "no sense of connotation." It is also counter to John's penchant "to make lists" (74) in order to stave-off confusion. Moreover, if we accept the proposition that psychoanalysis is its own critical language, in which translation and mistranslation are fundamentally important, then the older sister's-a psychoanalist-marriage with another psychoanalist has more to do with bilingual affinities than with the coincidence in careers.

Time after time, the García sisters establish productive relationships based on the manipulation of a second language. It happens from the opening chapter of the novel, when Yolanda finds herself in a dust road in the Dominican Republic with a flat tire. Suddenly, she cannot communicate with two men who approach her, apparently having forgotten the Spanish that she was speaking minutes ago with her aunts. Critics like Castell and Criado have interpreted this moment as Yolanda's attempt to assert a class-based superiority that hinges on the fact she can speak English. But Yolanda's pretension that she does not know Spanish seems, to me, to be in line with other deployments of a second language in the narrative: she knows that a gringa can get two men to fix that flat in a 
pinch, not because of her simulated unknowing of Spanish, but because the presumed handicap of being bilingual and bicultural can also be manipulated to one's advantage.

The relationship that bilinguals establish with their own languages are certainly not free from ambivalence. Neither are they straightforward love/hate relationships. That is a reason why, when Yolanda develops her allergy, Spanish provides no palliative. "Amor" is just as noxious as "love."

\section{Notes}

'I write "Alvarez" without an accent because this is how the author spells her name, and how it appears in most of the critical bibliography (in Spanish and English) about her ouevre. As in the case of Richard Rodriguez's surname, the loss of an accent may be read as a symptom of grammatical acculturation, but, we may ask, with names like "Alvarez" and "Rodriguez" in the United States, is the accent really needed to mark the author's difference?

ii Two examples of these problematic renderings of bilingualism in the novel occur in the work of Castells and Criado, in the list of works cited.

iii Julia Kristeva might add that this characteristic confusion of love leads to the profusion of metaphors we associate with it: "Let us call metaphor, in the general sense of a conveyance of meaning, the economy that modifies language when subject and object of the utterance act [sic] muddle their borders" (163). Previously in Tales of Love, Kristeva had warned that "it may seem paradoxical to be seeking the discourse of amatory relationships in borderline aesthetics" (162), but I find no paradox here. If love is muddled, as Kristeva and Nussbaum suggest, then it follows that it would be represented as such via "borderline aesthetics."

iv Roberto González Echevarría essentially agrees with Mary Gaylord when he writes that, in La Celestina, "All characters ultimately engage in this commerce, in which it is not only goods, but as Mary M. Gaylord has rightly seen, words, that are the most coveted commodity: 'Celestina's genius lies not only in her acute sensitivity to the desires of her fellow human beings, but in her recognition of the fact that human desire-physical, sexual, metaphysical-is in large part a hunger for words, a hunger which seeks not only to express itself, but also to satisfy itself verbally" (GonzálezEchevarría Celestina's 12). González Echevarría adds, however, that the most unfortunate moments take place in the tragicomedia when the symbols of language - the skein, girdle and chain exchanged by Celestina and other characters-are "stripped of its symbolic meanings" (20), becoming "not a set of neutral signs that convey information or desire, but objects by means of which the characters wound, disfigure, and ultimately kill each other" (20-21). Márquez Villanueva, on his part, does not go as far as declaring Celestina an emblem for language itself, but he does trace the history and sociology of la alcahueta, whose infamous linguistic virtuosity were deemed as dangerous even as late as the $19^{\text {th }}$ c: "Todavía en el siglo XIX sus asechanzas contra la castidad femenina 
se encarecen como diabólicas y se la caracteriza como personaje de cuya boca salen toda suerte de engaños e incitaciones pecaminosas" (112).

${ }^{\vee}$ Fatima Mujcinovic has pointed out that Alvarez's work explores the ways that femininity and masculinity are reconstituted through migration. This exploration, we should note, does not entail a radical critique of gender roles nor of non-heterosexual sexualities. Non-normative sexualities are often mentioned in passim in Alvarez's narrative to contrast Island mores to those of neo-liberal New England. In The García Girls, for example, though lesbianism and homosexuality are mentioned in passing $(110,119$, 125), pertaining to characters in both New York and the Dominican Republic, the very mention of homosexuality, and not homosexuality itself, is interpreted as a sign of acculturation, as happens when the college-bound Yolanda brings home a copy of Our Bodies, Our Selves (110). Her mother is, predictably, scandalized. In iYo! we do find a sustained representation of homosexual relationships $(73-96 ; 213-240)$, one of them (213-240), again, used to contrast Dominican values with progressive Vermont.

vi In her analysis of female masculinity, Halberstam notes that tomboyism is, indeed, tolerated during childhood and early adolescence. However, during early adulthood it starts to be seen as a problem that needs to be tamed or corrected.

\section{Works Cited}

Albin, Verónica and Stavans, llan. Love \& Language. New Haven: Yale UP, 2007.

Alvarez, Julia. De cómo las chicas García perdieron su acento. Trans. Jordi Gubern. Barcelona: Ediciones B, 1994. -How the García Girls Lost Their Accents. New York: Penguin, 1991. Yo!. Chapel Hill: Algonquin, 1997.

Anzaldúa, Gloria. Borderlands/La frontera: The New Mestiza. San Francisco: Aunt Lute, 1987.

Augenbraum, Harold and Ilan Stavans, eds. "Introduction." Lengua fresca: Latinos Writing on the Edge. Boston: Houghton Mifflin, 2006.

Butler, Judith. "Imitation and Gender Insubordination". Inside/Out.: Lesbian Theories, Gay Theories. Ed. Diana Fuss. New York: Routledge, 1991. 13-31.

Caruth, Cathy. Unclaimed Experience: Trauma, Narrative and History. Baltimore: Johns Hopkins UP, 1996.

Castells, Ricardo. "The Silence of Exile in How the García Girls Lost Their Accents." Bilingual Review/La Revista Bilingüe. 26 (2001): 34-42.

Criado, Miryam. "Lenguaje y otredad sexual/cultural en How the García Girls Lost Their Accents." Bilingual Review/La Revista Bilingüe 23.3 (Sept.-Dec. 1998): 195-205.

Derrida, Jacqes. Monolingualism of the Other, or, The Prosthesis of Origin. Trans. Patrick Mensah. Stanford: Stanford UP, 1998.

González Echevarría, Roberto. Celestina's Brood: Continuities of the Baroque in Spanish and Latin American Literatures. Durham: Duke UP, 1993.

--------Lecture on "Viaje a la semilla." Course on The Short Story in Latin America. Yale University, Spring 1998.

Halberstam, Judith. Female Masculinity. Durham: Duke UP, 1998.

Irizarry, Guillermo. "Traveling Textualities and Phantasmagoric Originals: A 
Reading of Translation in Three Recent Spanish-Caribbean Narratives." CiberLetras: Revista de crítica literaria y de cultura/Journal of Literary Criticism and Culture 4 Jan. 2001 <http://www.lehman.cuny.edu/ciberletras/>.

Kristeva, Julia. "Throes of Love: The Field of Metaphor (abridged)." The Portable Kristeva. Ed. Kelly Oliver. New York: Columbia UP, 2002. 162-170.

Langford, Wendy. "'Bunnikins, I Love You Snugly in Your Warren' Voices from Subterranean Cultures of Love." Eds. Keith Harvey and Celia Shalom. Language and Desire: Encoding Sex, Romance and Intimacy. London and New York: Routledge, 1997. 170-185.

Luis, William. Dance Between Two Cultures: Latino Caribbean Literature Written in the United States. Nashville: Vanderbilt UP, 1997.

Ludmer, Josefina. "Literaturas postautónomas." CiberLetras: Revista de crítica literaria y de cultura/Journal of Literary Criticism and Culture 17 July 2007 $<$ http://www. lehman.cuny.edu/ciberletras/>.

Márquez Villanueva, Francisco. Orígenes y sociología del tema celestinesco. Barcelona: Anthropos, 1993.

Mujcinovic, Fatima. "Multiple Articulations of Exile in U.S. Latina Literature: Confronting Exilic Absence and Trauma." MELUS: Journal of the Society for the Study of Multi-Ethnic Literature of the United States 28.4 (Winter, 2003): 167186.

Nussbaum, Martha. Love's Knowledge: Essays on Philosophy and Literature. New York and Oxford: Oxford UP, 1990.

Ovid. The Love Books of Ovid. Trans. J. Lewis May. 1930. <http://www.sacred-texts. com/cla/ovid/index.htm> Accessed 13 May 2008.

Patterson, Richard E. "Resurrecting Rafael: Fictional Incarnations of a Dominican Dictator." Callaloo: A Journal of African Diaspora Arts and Letters 29.1 (Winter 2006): 223-37.

Sommer, Doris. Bilingual Aesthetics: A New Sentimental Education. Durham and London: Duke UP, 2004.

Trigo, Benigno. Remembering Maternal Bodies: Melancholy in Latina and Latin American Women's Writing. New York: Palgrave Macmillan, 2006.

Vargas Llosa, Mario. La Fiesta del Chivo. 2000. Madrid: Suma de Letras, 2001.

Juan Pablo Rivera is Assistant Professor of Latin American Culture, Department of World Language Studies, Westfield State College, USA.

Email: drjprivera@gmail.com 